\title{
DETECTION OF Toxoplasma gondii SOLUBLE ANTIGEN, SAG-1(p30), ANTIBODY AND IMMUNE COMPLEX IN THE CEREBROSPINAL FLUID OF HIV POSITIVE OR NEGATIVE INDIVIDUALS
}

\author{
Flávia A. CHAVES-BORgeS(1), Maria A. SOUZA(1), Deise A. O. SILVA(1), Lloyd H. KASPER(2) \& José R. MINEO(1)
}

\begin{abstract}
SUMMARY
Active infection by $T$. gondii was evaluated by immunoassay for soluble SAG-1 (p30), the major surface antigen from $T$. gondii, specific antibodies and immune complexes in human cerebrospinal fluid (CSF) samples. A total of 263 samples of CSF were collected from hospitalized patients presenting neurological disorders and analyzed for antibodies to HIV. Patients were divided into two groups: HIV positive $(n=96)$ or HIV negative $(n=167)$. The results of the assays showed that $45 \%$ of all samples were positive for soluble SAG-1. Toxoplasma Ag/Ab immune complexes were detected in $19 \%$ of the CSF samples and $62 \%$ were positive for $T$. gondii- specific IgG. A combination of these assays in the presence of clinical findings consistent with active Toxoplasma infection may predict the presence of toxoplasmic encephalitis. Moreover, detection of soluble SAG-1 in the CSF of these individuals appears consistent with active infection.
\end{abstract}

KEYWORDS: T. gondii; SAG-1 (p30) antigen; AIDS; Encephalitis; Human cerebrospinal fluid

\section{INTRODUCTION}

Toxoplasma gondii, an intracellular coccidian, infects a wide range of eukaryotic cells and is an important opportunistic pathogen in humans and animals. The infection is frequently encountered without any symptom but there are two groups of high-risk individuals, the human fetuses and the immunosuppressed persons, particularly those with acquired immunodeficiency syndrome (AIDS), that frequently develop fatal toxoplasmic encephalitis (TE) ${ }^{29}$. In these patients, the diagnosis relies on a compatible clinical presentation, serologic evidence of exposure to $T$. gondii, and the presence of cerebral lesions by imaging (either MRI or $\mathrm{CT}$ ). The diagnosis is confirmed if a response to specific treatment is observed within 20 days, as determined by radioimaging scan. However, there are limiting factors to this treatment strategy. For example, the level of antibody may not be correlated with active infection and furthermore unnecessary therapy can be dangerous because of the potential for bone marrow toxicity with anti-T. gondii drugs. Therefore, accurate diagnosis of toxoplasma infection is essential for improved prognosis.

Toxoplasma gondii has several molecular components that have been evaluated as possible diagnostic tools. A group of proteins from 26$38 \mathrm{kDa}$ can be detected, by Western blot, in cerebrospinal fluids and serum of patients, during toxoplasmosis ${ }^{41}$. The major surface protein of the parasite, SAG-1 (p30) is included among these proteins ${ }^{23}$. This protein belongs to a group of excreted-secreted antigens (ESA) ${ }^{3,7,35}$ and is involved in host immunity ${ }^{38}$. Polyclonal antibodies to p30 have been identified in the serum of acute and chronically infected patients and in congenitally infected individuals.

P30 antigen is stage-specific in that it is expressed exclusively by tachyzoites that are the fast replicative form of the parasite. This molecule is involved in parasite attachment ${ }^{14,31}$ and could represent an important indicator of active infection since it can be a circulating antigen ${ }^{7,37}$.

Immunoenzymatic assays, ELISA (Enzyme-linked Immunosorbent Assay), have been used in the diagnostics of toxoplasmosis ${ }^{6,12,30}$. Quantification of antigenemia has been studied by ELISA and immunoblot method ${ }^{1,2,4,16}$.

The polymerase chain reaction (PCR) has been successfully applied to detect Toxoplasma DNA or RNA in the cerebrospinal fluid of groups of AIDS patients ${ }^{15,26}$. However, it has been recently demonstrated that PCR, although diagnostics for primary infection, may be of a limited value for diagnosis of toxoplasmic encephalitis in AIDS patients ${ }^{10}$. Detection of parasite nucleic acid by PCR may be not correlated with active infection since chronic infection may be associated with intervals of parasitemia during asymptomatic phases of the disease $\mathrm{e}^{9,24}$.

In the present study, we describe an ELISA system for simultaneous detection of soluble SAG-1 (p30) antigen, IgG antibodies to T. gondii and immune complex in human cerebrospinal fluid (CSF) samples in those who are HIV seropositive.

(1) Laboratory of Immunology, Department of Pathology, Universidade Federal de Uberlândia, 38400-902 Uberlândia, MG, Brazil.

(2)Department of Medicine (Neurology) and Microbiology, Dartmouth Medical School, Lebanon, New Hampshire, USA, 03756.

Correspondence to: Dr. J. R. Mineo, Department of Pathology, Universidade Federal de Uberlândia. 38400-902 Uberlândia, MG, Brazil. E-mail: jrmineo@ ufu.br 


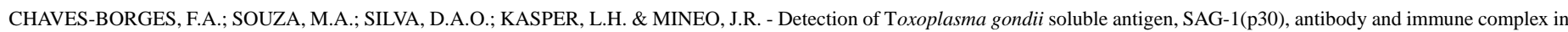
the cerebrospinal fluid of HIV positive or negative individuals. Rev. Inst. Med. trop. S. Paulo, 41(6): 329-338, 1999.

\section{MATERIALS AND METHODS}

Cerebrospinal fluid samples. This work was conducted in accordance with the guidelines of the Ethical Committee at the General Hospital at University of Uberlândia.

A total of 263 cerebrospinal fluid (CSF) samples were randomly obtained at the Clinical Laboratory of the General Hospital of the Federal University of Uberlândia, from July 1994 to April 1996. All samples were kept at $-20{ }^{\circ} \mathrm{C}$ until be tested.

After being tested for simultaneous detection of soluble SAG-1 (p30) antigen, $\mathrm{IgG}$ antibodies to $T$. gondii and immune complex, the results of these samples were retrospectively analyzed with the clinical data presented at the files from those patients.

Production of anti-P30 monoclonal antibodies. BALB/c mice were immunized i.p. with $1.5 \times 10^{7}$ tachyzoites of $T$. gondii RH strain previously treated by acetone at $30 \%$ for $72 \mathrm{~h}$ at $4{ }^{\circ} \mathrm{C}$, at days $0,14,28$ and 42 . At day 46 , the spleen was removed and the spleen cells were fused with $\mathrm{SP}_{2} \mathrm{O} / \mathrm{Ag} 14^{17}$. The supernatants of hybridomas growing under the HAT selection were screened for anti- $T$. gondii antibodies by an indirect ELISA. The positive hybridomas were expanded and the cells were cloned by limiting dilution, being further assessed by another screening round. The positive clones were characterized by Western blot against SDS T. gondii lysates, demonstrating reactivity to a band of 30 $\mathrm{kDa}(\mathrm{p} 30)$. Further characterization was carried out by isotyping of antip30 monoclonal antibodies using the Mouse Typer-Bio-Rad Kit (Hercules, USA). 6A8 mAb to p30, which was obtained as described, was used as a positive control ${ }^{31}$.

Excreted-secreted antigens (ESA) T. gondii $\mathrm{RH}$ strain tachyzoites were harvested from mice peritoneal exsudates 2 days after the inoculation of parasites. The suspension was selected when parasite containing ranged from $10^{7}$ to $10^{8}$ parasites $/ \mathrm{ml}$, followed by centrifugation at $1000 \mathrm{~g}$ for 15 min. The sediment was resuspended in $10 \mathrm{ml}$ of sterile PBS at $4{ }^{\circ} \mathrm{C}$ and centrifuged again at the same conditions as above described. The sediment was resuspended in $0.5 \mathrm{ml}$ of sterile PBS, and incubated at $37^{\circ} \mathrm{C}$ for 45 min under eventual stirrings and centrifuged at $1000 \mathrm{~g}$ for $15 \mathrm{~min}$. The supernatant was filtered in $0.2 \mu \mathrm{m}$ membrane (Sterile Acrodisc 13, Gelman Sciences, USA) and was stored at $-20^{\circ} \mathrm{C}$. The protein concentration of the ESA was determined by using bovin serum albumin as standard ${ }^{28}$. The electrophoretic profile of the ESA proteins was analyzed by SDS$\mathrm{PAGE}^{25}$ in $15 \%$ gel without reducing conditions and stained by silver stain $^{13}$. The p30 relative concentration in the ESA preparations was estimated by densitometry in different samples of the metabolic antigen. The determination was performed in a densitometer at $525 \mathrm{~nm}$ (Helena J. France S.A., Saint-Leula, Forêt, France).

P30 antigen detection. Monoclonal anti-p30 antibodies (6A8 and 6E9) were coated onto wells of polyvinylchloride microtiter plates (Falcon, Oxnard, USA) at concentration of $50 \mu \mathrm{g} / \mathrm{ml}$. The volume added was $50 \mu \mathrm{l} /$ well and the plates were incubated in a humid chamber, for $18 \mathrm{~h}$ at $4{ }^{\circ} \mathrm{C}$. After this incubation, the plates were washed three times for 5 minutes with PBS-T 0.05\% (Sigma, St. Louis, USA). Following washing, $50 \mu \mathrm{l} /$ well of each CSF sample was added and incubated for $2 \mathrm{~h}$ at $37^{\circ} \mathrm{C}$. The negative controls consisted of CSF samples obtained from patients negative for anti-HIV and for $\mathrm{p} 30$ antigen, anti-T. gondii antibodies and immune complex. ESA was added to samples with this same profile in order to obtain positive controls. Plates were incubated for $2 \mathrm{~h}$ at $37{ }^{\circ} \mathrm{C}$, in a humid chamber and were washed again three times. A volume of $50 \mu \mathrm{l} /$ well of the biotinylated mouse IgG anti T.gondii was added after diluted $1 / 200$ in PBS-T $0.05 \%$. The reaction was incubated for $45 \mathrm{~min}$ at $37{ }^{\circ} \mathrm{C}$ and then washed in the same conditions described above. The avidin-biotin system (ABC-Vectastain Kit, Vector Laboratories, Inc., Burlingame, CA, USA) was used according to manufacturer instructions and, after incubation for 45 min and washes, the substrate solution was added. This consisted of a solution of $\mathrm{H}_{2} \mathrm{O}_{2}$ and o-phenylenediamine (Merk, Schchardt, Germany) in $0.1 \mathrm{M}$ citrate- $\mathrm{Na}_{2} \mathrm{HPO}_{4}$ buffer, $\mathrm{pH}$ 5.5. The reaction was stopped after 15 min with $2 \mathrm{~N} \mathrm{H}_{2} \mathrm{SO}_{4}$. The reading was carried out at $492 \mathrm{~nm}$ in a spectrophotometer microwell reader system (Organon Teknika, Belgium) at $492 \mathrm{~nm}$.

Anti-T. gondii IgG detection. Polyvinylchloride microplates were coated with $50 \mu \mathrm{l}$ of ESA antigen $(5 \mu \mathrm{g} / \mathrm{ml})$ for $18 \mathrm{~h}$ at $4{ }^{\circ} \mathrm{C}$. The plates were washed three times with phosphate-buffered saline $0.01 \mathrm{M} \mathrm{pH} 7.2$ containing $0.1 \%$ Tween-20 (PBS-T) and blocked during $30 \mathrm{~min}$ at room temperature with 5\% goat serum in PBS-T. After a new cycle of washes, $50 \mu \mathrm{l}$ of undiluted CSF samples were added in duplicate and incubated for $45 \mathrm{~min}$ at $37^{\circ} \mathrm{C}$. As controls, it was used negative and positive CSF samples for IgG anti-T. gondii antibody, and controls for conjugate and substrate, as well. Microplates were washed three times and $50 \mu \mathrm{l}$ of goat IgG anti-human IgG peroxidase (Sigma, St. Louis, USA), diluted $1 / 4000$ in PBS-T, were added and incubated for $45 \mathrm{~min}$ at $37^{\circ} \mathrm{C}$. After another series of washes, as described above, the plates were incubated with substrate solution consisting of $\mathrm{H}_{2} \mathrm{O}_{2}$ and o-phenylenediamine in $0.1 \mathrm{M}$ citrate- $\mathrm{Na}_{2} \mathrm{HPO}_{4}$ buffer ( $\mathrm{pH}$ 5.5) for $15 \mathrm{~min}$ at room temperature. The reaction was stopped with $2 \mathrm{~N} \mathrm{H}_{2} \mathrm{SO}_{4}$ and the absorbance was determined at microwell reader system (Organon Teknika, Belgium) at $492 \mathrm{~nm}$.

Immune complex detection. Polyvinylchloride microplates were coated for $18 \mathrm{~h}$ at $4{ }^{\circ} \mathrm{C}$ with $50 \mu \mathrm{l}$ of IgG obtained from supernatants of $6 \mathrm{~A} 8$ and $6 \mathrm{E} 9 \mathrm{mAbs}(50 \mu \mathrm{g} / \mathrm{ml})$. After three washes with PBS-Tween 20 $(0.05 \%), 50 \mu \mathrm{l} /$ well of undiluted CSF samples were added and incubated for $2 \mathrm{~h}$ at $37^{\circ} \mathrm{C}$. Positive and negative CSF samples to immune complex were used as control. The positive CSF samples consisted of a positive sample for anti $-T$. gondii $\mathrm{IgG}$ which was added of ESA and pre-incubated for $1 \mathrm{~h}$ at $37^{\circ} \mathrm{C}$. After incubation for $45 \mathrm{~min}$ at $37^{\circ} \mathrm{C}$ and a new cycle of washes, it was added the conjugate goat IgG anti- human IgG-peroxidase. After incubation for $45 \mathrm{~min}$ at $37{ }^{\circ} \mathrm{C}$ and another three washes, the substrate solution was added $(50 \mu \mathrm{l} /$ well) and the reaction was stopped as previously described.

ELISA sensitivity and specificity for P30 antigen detection. To determine the sensitivity of the P30 ELISA, the CSF samples were substituted by ESA solutions diluted in PBS-T $0.05 \%$. The end point was obtained with the maximum dilution in which the absorbance values were higher than those obtained with the negative controls, determined as cut off values. The sensitivity was calculated based in P30 concentrations, obtained by densitometry as above described. The specificity of the P30 ELISA was determined by assessing 29 different antigenic extracts of microorganisms widely spread in nature, obtained by preparation of soluble extracts as generally used for intradermic cutaneous tests (Alerbras and Alergofar, Rio de Janeiro, Brasil): Candidina, 
Escherichia coli, PPD, Tricofitina, Estreptoquinase/Estreptodornase, Aspergillus sp., Alternaria sp., Cladosporium sp., Rhizopus sp., Penicillium sp., Rhodotorula sp., Diplococcus pneumoniae, Streptococcus viridiam, Streptococcus dyogene, Streptococcus faecalis, Neisseria catarrhalis, Staphylococcus sp., Aerobacter aeruginosa, Proteus vulgaris, Salmonella group, Klebsiella pneumoniae, Shigella group, Staphylococcus toxoids, Streptococcus toxoids, Haemophilus influenzae, T. cruzi, Leishmania amazonensis, cetonic extract of Dengue virus and soluble extract of Cysticercus cellulosae. All these preparations had a protein concentration varying from 20 to $25 \mu \mathrm{g}$. ESA preparation $(19.5 \mu \mathrm{g})$ and PBS were used, as positive and negative controls, respectively.

Indirect ELISA for anti-HIV IgG detection. The reactions for the detection of anti-HIV IgG in the CSF samples were carried out using anti-HTLV-III Kit ("Vironostika" Organon Boxtel,) following the instructions of the manufacturer. The CSF samples were assayed undiluted at one volume of $50 \mu \mathrm{l}$.

Statistical analysis. The results of the studied tests were analyzed by the "Statistic for Windows- Release 4.5 A" program (Statesoft, Inc. 1993). $X^{2}$, McNemar and Fisher's exact tests were performed for evaluation of the differences between two or more proportions. The null hypothesis was rejected when $\mathrm{p}<.05$.

\section{RESULTS}

Characterization of the assays. Samples of excreted-secreted antigens were obtained (protein concentrations from .38 to $1.7 \mathrm{mg} / \mathrm{ml}$ ) and analyzed by SDS-PAGE. Following staining and densitometry, the concentration of SAG-1 was determined and the sensitivity of the assay was estimated at a minimum of $5 \mathrm{ng}$. Specificity was investigated against unrelated antigens, with 29 samples comprising a group of pathogens commonly found in nature. By taking the cut off as the medium value of negative controls plus 3 standard-deviations, all these samples displayed absorbances lower than the cut off, thus evidencing the specificity of the test for detection of SAG-1 (p30).

Detection of soluble SAG-1(p30), antibody and immune complex in CSF samples. Among the 263 CSF samples examined, 96 (37\%) were diagnosed as positive to HIV and $167(63 \%)$ samples had negative results. A total of $164(62 \%)$ CSF samples were positive to anti-T. gondii IgG and $99(38 \%)$ were negative.
Table 1 shows the results of simultaneous detection of the markers P30 /Ab/IC among the test population. Among the $96 \mathrm{HIV}$ seropositive group, $69(72 \%)$ exhibited anti-T. gondii IgG whereas among the 167 anti-HIV negative samples, $95(57 \%)$ were positive. There were no significant differences between the prevalence of anti-T. gondii IgG antibodies in the HIV positive samples and HIV negative samples $(\mathrm{p}=0.2349)$.

P30 was detected in 119 (45\%) of the CSF samples. Among the anti-HIV positive and negative samples, the positivity of $\mathrm{p} 30$ protein was $54 \%$ and $40 \%$, respectively, showing a statistically significant difference between these two groups $(\mathrm{p}<0.05)$ (Table 1).

Immune complex (IC) was detected in 50 samples (19\%). Its incidence was higher in samples of the group of the HIV positive patients $(29 \%)$ than in the samples of the HIV negative group $(13 \%)(\mathrm{p}=0.0009)$ (Table 1).

The analysis of the results showed that positive results for both $\operatorname{IgG}$ anti-T. gondii and p30 antigen were found in 35\% of the total CSF samples. Positive results for anti-T. gondii and negative results for $\mathrm{p} 30$ antigen were found in $27 \%$, whereas negative results for anti-T. gondii and positive results for P30 were observed in $10 \%$ of the samples ( $\mathrm{p}<$ 0.001) (Table 1).

The incidence of IC was higher in positive IgG anti-T. gondii samples $(17 \%)$ than in negative samples $(2 \%)\left(X_{2}=16.98 ; \mathrm{p}=0.0001\right)$ and was higher in $\mathrm{p} 30$ positive samples $(16 \%)$ compared to $\mathrm{p} 30$ negative samples $(3 \%)\left(\mathrm{X}_{2}=12.29 ; \mathrm{p}<0.001\right)$.

Positive results for the three markers were found in 37 samples (14\%) and results entirely negative were found in $72(27 \%)$ of the samples. Positive samples for detection of p30 antigen or antibody were found in $21(8 \%)$ and $65(25 \%)$ of the studied samples, respectively.

Further comparison of these results was done based on the reactivity for HIV infection. It was observed that the incidence of positive results for all markers was higher in the HIV positive group (20\%) than in the HIV negative group $(11 \%)(\mathrm{p}<0.05)$. Considering the detection of at least one marker, represented by the SAG-1 (p30) antigen or immune complex, as indicative of active infection, the HIV positive group also showed higher incidence than the HIV negative group $(p<0.01)$. Figure 1 shows the correlation between the quantitative data for $\mathrm{p} 30$ and IC assays, demonstrating a significant correlation index for both HIV

Table 1

Results of the detection of molecular markers P30/Ab/IC (p30 soluble antigen, IgG anti-T. gondii and immune complex) obtained by immunoenzymatic assays in 263 cerebrospinal fluid samples that were positive or negative for IgG anti-HIV

\begin{tabular}{lcccccccc}
\hline & & \multicolumn{7}{c}{ Detection of P30 antigen, IgG antibody or Immune complex ${ }^{\text {a }}$} \\
\hline PIV+ & P30/Ab/IC & P30/Ab & P30/IC & P30 & Ab/IC & Ab & No detection & Total \\
\hline HIV- & 19 & 23 & 4 & 6 & 5 & 22 & 17 & 96 \\
\hline Total & 37 & 32 & 2 & 15 & 2 & 43 & 55 & 167 \\
\hline
\end{tabular}

a $(\mathrm{P} 30)=$ p30 antigen, major surface antigen of T. gondii; $(\mathrm{Ab})=$ IgG antibody to T. gondii; $(\mathrm{IC})=$ immune complex 

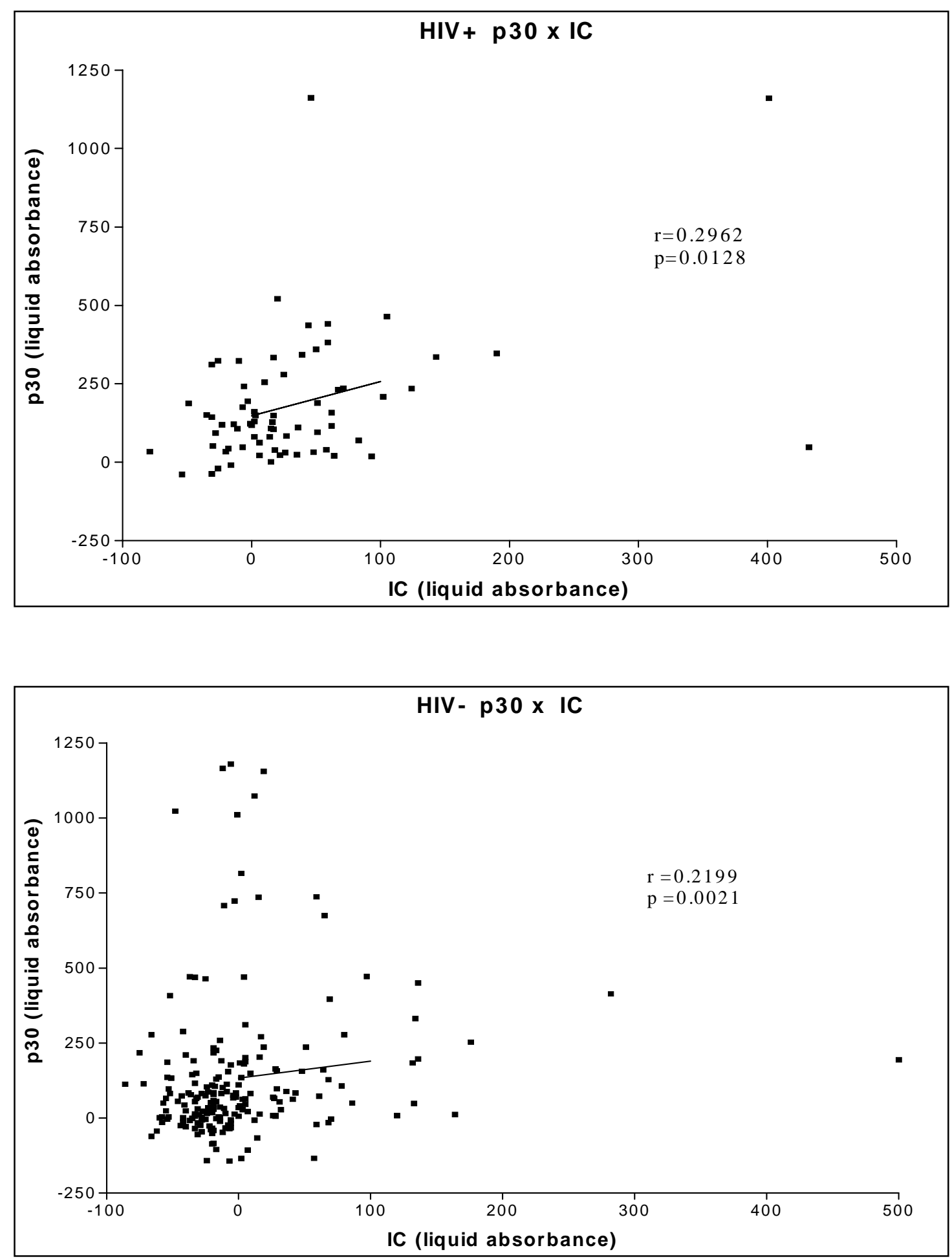

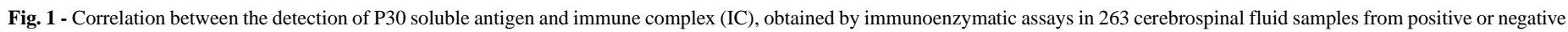
IgG anti-HIV patients. 
positive and HIV negative samples $(\mathrm{p}=0.0128$ and $\mathrm{p}=0.0021$, respectively).

Association of clinical data with the results of the CSF markers. The presence of active infection was defined when the $\mathrm{P} 30$ antigen and/or Immune complex assays was/were positive in CSF samples. As demonstrated in Table 2 and according to the clinical data presented in the patient files, it was observed that the active infection was present in all groups, in samples from both HIV positive and negative patients.
Detection of p30 /Ab/IC in CSF samples from children. Figure 2 shows the results of simultaneous detection of the studied markers among 17 CSF samples from children aged from newborn to 12-month old. These samples were also tested for the presence of anti-HIV antibodies. It was found that $65 \%$ of these samples were positive for $\mathrm{p} 30$ and, among these, $36 \%$ were positive exclusively for this marker. The detection of $\mathrm{P} 30 / \mathrm{Ab} / \mathrm{IC}$ showed no significant difference between the HIV positive and HIV negative groups.

Table 2

Evidence of active T. gondii infection among HIV positive and HIV negative CSF samples according to the clinical data presented in the patient files

\begin{tabular}{|c|c|c|c|}
\hline \multirow[t]{2}{*}{ Clinical Hypothesis } & \multirow{2}{*}{$\begin{array}{c}\text { Evidence of active } \\
\text { infection }^{\mathrm{a}}\end{array}$} & \multicolumn{2}{|c|}{ Anti-HIV antibodies } \\
\hline & & Positive & Negative \\
\hline $\begin{array}{l}\text { Cerebral toxoplasmosis } \\
\text { (acquired or congenital) }\end{array}$ & $13 / 26(50 \%)$ & 9 & 4 \\
\hline $\begin{array}{l}\text { Other CNS infectious diseases } \\
\text { (cysticercosis, syphylis, } \\
\text { cryptococcosis, meningococcal or } \\
\text { asseptic meningitis) }\end{array}$ & $30 / 63(48 \%)$ & 13 & 17 \\
\hline Not infectious CNS diseases & $44 / 103(43 \%)$ & 15 & 29 \\
\hline Not available clinical data & $39 / 71(55 \%)$ & 20 & 19 \\
\hline Total & $126 / 263(48 \%)$ & 57 & 69 \\
\hline
\end{tabular}

${ }^{a}$ ratio between the number of samples presenting active infection and the total number of samples. The presence of active infection was defined when the P30 antigen and/or Immune complex assays was/were positive in CSF samples.

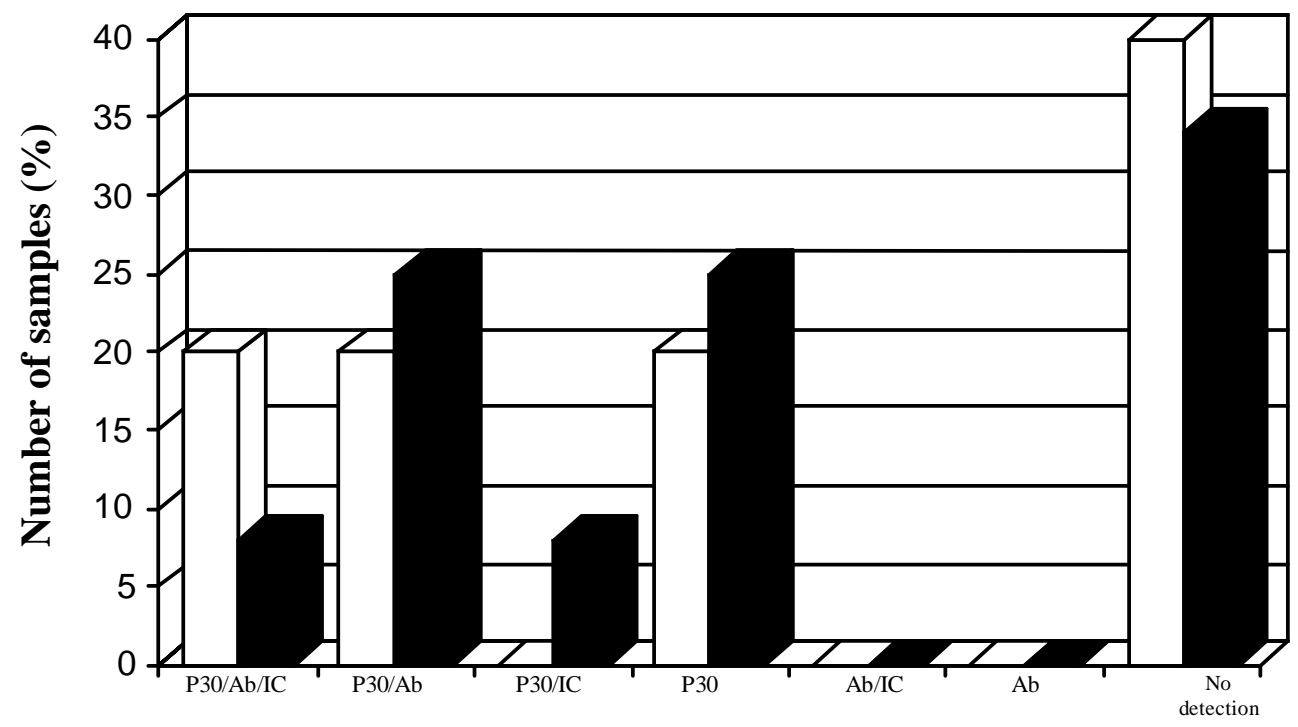

Detection of P30 antigen, IgG antibody or Immune complex

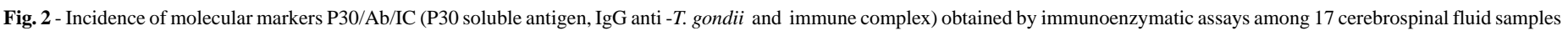
from children under 1 year-old that were positive (white columns) or negative (black columns) for IgG anti-HIV. 


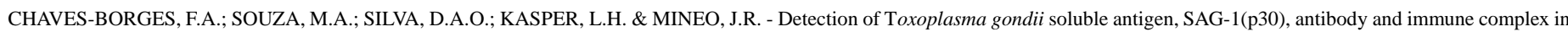
the cerebrospinal fluid of HIV positive or negative individuals. Rev. Inst. Med. trop. S. Paulo, 41(6): 329-338, 1999.

Table 3

Association of clinical signs obtained in the files of 17 patients aged from newborn to 12 month-old with the ELISA results to SAG-1 (p30) T. gondii antigen, antibody, and immune-complex in cerebrospinal fluid samples

\begin{tabular}{|c|c|c|c|c|c|c|c|c|c|c|c|c|}
\hline \multirow{3}{*}{$\begin{array}{l}\text { Sample } \\
\text { Number }\end{array}$} & \multirow{3}{*}{ Age } & \multicolumn{10}{|c|}{$\begin{array}{c}\text { Detection of p30 antigen (P30), Antibody (Ab) and/or } \\
\text { Immune-complex (IC) }\end{array}$} & \multirow{3}{*}{$\begin{array}{l}\text { Clinical signs } \\
\text { in the patient files }\end{array}$} \\
\hline & & \multicolumn{2}{|c|}{ P30/Ab/IC } & \multicolumn{2}{|c|}{ P30/Ab } & \multicolumn{2}{|c|}{ P30/IC } & \multicolumn{2}{|c|}{ P30 } & \multicolumn{2}{|c|}{ No detection } & \\
\hline & & $\begin{array}{c}\text { HIV } \\
+\end{array}$ & $\begin{array}{c}\text { HIV } \\
-\end{array}$ & $\begin{array}{c}\text { HIV } \\
+\end{array}$ & $\begin{array}{c}\text { HIV } \\
-\end{array}$ & $\begin{array}{c}\text { HIV } \\
+\end{array}$ & $\begin{array}{c}\text { HIV } \\
-\end{array}$ & $\begin{array}{c}\text { HIV } \\
+\end{array}$ & $\begin{array}{c}\text { HIV } \\
-\end{array}$ & $\begin{array}{c}\text { HIV } \\
+\end{array}$ & $\begin{array}{c}\text { HIV } \\
-\end{array}$ & \\
\hline 1 & $12 \mathrm{~m}$ & & & & $\mathbf{x}$ & & & & & & & Congenital toxoplasmosis \\
\hline 2 & $11 \mathrm{~m}$ & & $\mathbf{x}$ & & & & & & & & & Cerebral paralysis \\
\hline 3 & $12 \mathrm{~m}$ & & & $\mathbf{x}$ & & & & & & & & Hydrocephalus Myelomeningocele \\
\hline 4 & $3 \mathrm{~m}$ & & & & $\mathbf{x}$ & & & & & & & Hydrocephalus \\
\hline 5 & $3 m$ & & & & $\mathbf{x}$ & & & & & & & Hydrocephalus \\
\hline 6 & NB & & & & & & & $\mathbf{x}$ & & & & $\begin{array}{l}\text { Cerebral malformation, with areas of } \\
\text { encephalic absence }\end{array}$ \\
\hline 7 & $1 \mathrm{~m}$ & & & & & & & & & & $\mathbf{x}$ & Malnutrition, anemia, dehydratation \\
\hline 8 & NB & $\mathbf{x}$ & & & & & & & & & & Intracraniane hemorrhage, hydrocephalus \\
\hline 9 & NB & & & & & & & & & $\mathbf{x}$ & & NA \\
\hline 10 & NB & & & & & & & & $\mathbf{x}$ & & & Arm muscle tonus disturbs \\
\hline 11 & $2 \mathrm{~m}$ & & & & & & & & $\mathbf{x}$ & & & NA \\
\hline 12 & $12 \mathrm{~m}$ & & & & & & & & & & $\mathbf{x}$ & Treated bacterial meningitis \\
\hline 13 & $12 \mathrm{~m}$ & & & & & & & & & & $\mathbf{x}$ & Hydrocephalus \\
\hline 14 & $12 \mathrm{~m}$ & & & & & & & & & & $\mathbf{x}$ & Convulsions \\
\hline 15 & $12 \mathrm{~m}$ & & & & & & $\mathbf{x}$ & & & & & Cerebral cysts, meningitis \\
\hline 16 & $1 \mathrm{~m}$ & & & & & & & & & $\mathbf{x}$ & & Marasmus, vomit \\
\hline 17 & $1 \mathrm{~m}$ & & & & & & & & $\mathbf{x}$ & & & Congenital syphilis \\
\hline
\end{tabular}

$\mathrm{m}=$ month $\mathrm{NB}=$ newborn $\quad \mathbf{X}=$ association between test results and clinical data $\mathrm{NA}=$ not available

Association of clinical data with the results obtained in the CSF samples from children. Table 3 shows that the results expressing active infection accomplished $65 \%$ of the samples. Among ten patients presenting at least one symptom related to the Sabin's tetrad, $8(80 \%)$ of them presented CSF samples considered positive for active infection. Five out of nine samples with clinical evidences of other diseases were totally negative for $\mathrm{p} 30, \mathrm{IgG}$ antibody and immune complex. The remaining four samples were positive for only the p30 antigen. In addition, the presence of $\mathrm{p} 30$ and IC was occurred in 6/7 children with clinical signs of hydrocephalus and generalized brain affection as compared with $0 / 10$ in other diseases. Even if the two cases without clinical diagnosis will be excluded, it was observed a significant definition of those tests in this group of patients $(\mathrm{p}=0.0014)$.

Detection of $\mathrm{p} 30 / \mathrm{Ab} / \mathrm{IC}$ in multiple CSF samples from AIDS patients. Figure 3 shows the results of simultaneous detection of the markers p30/Ab/IC in multiple samples from 3 patients who were HIV positive and had clinical symptoms of toxoplasma encephalitis. It was observed that the detection of p30 was positive in these individuals. Moreover, there was a significant increase in reactivity of the CSF samples during disease progression. In only one patient the p30 detection was accomplished by the detection of antibody against $T$. gondii and increasing amounts of immune complex (Figure 3B).

\section{DISCUSSION}

The diagnosis of $T$. gondii infection in humans can be determined by a variety of immunological molecular methods. The identification of the parasite in blood and other organic fluids or in tissue can confirm the etiology of the infection. Although presence of tissue cysts and free tachyzoites in brain or in placenta is diagnostic, it is impractical. Current parasitologic methods for the detection of parasites are at insufficient sensitivity for accurate detection of infection in the newborn or compromised host. Therefore, the methods dealing with anti-T. gondii antibody or circulating antigen detection are more widely used. The methodology for antibody detection is well established, allowing the identification of serologic profiles, correlated with the stage of the infection ${ }^{5,6}$. The presence of circulating antigen from the parasite in infected human beings has been intensively investigated and consists in an important indicator of active infection. So far, it has been described that the detection of circulating antigen has limited value in the immunocompromised individuals or newborns ${ }^{27}$. 

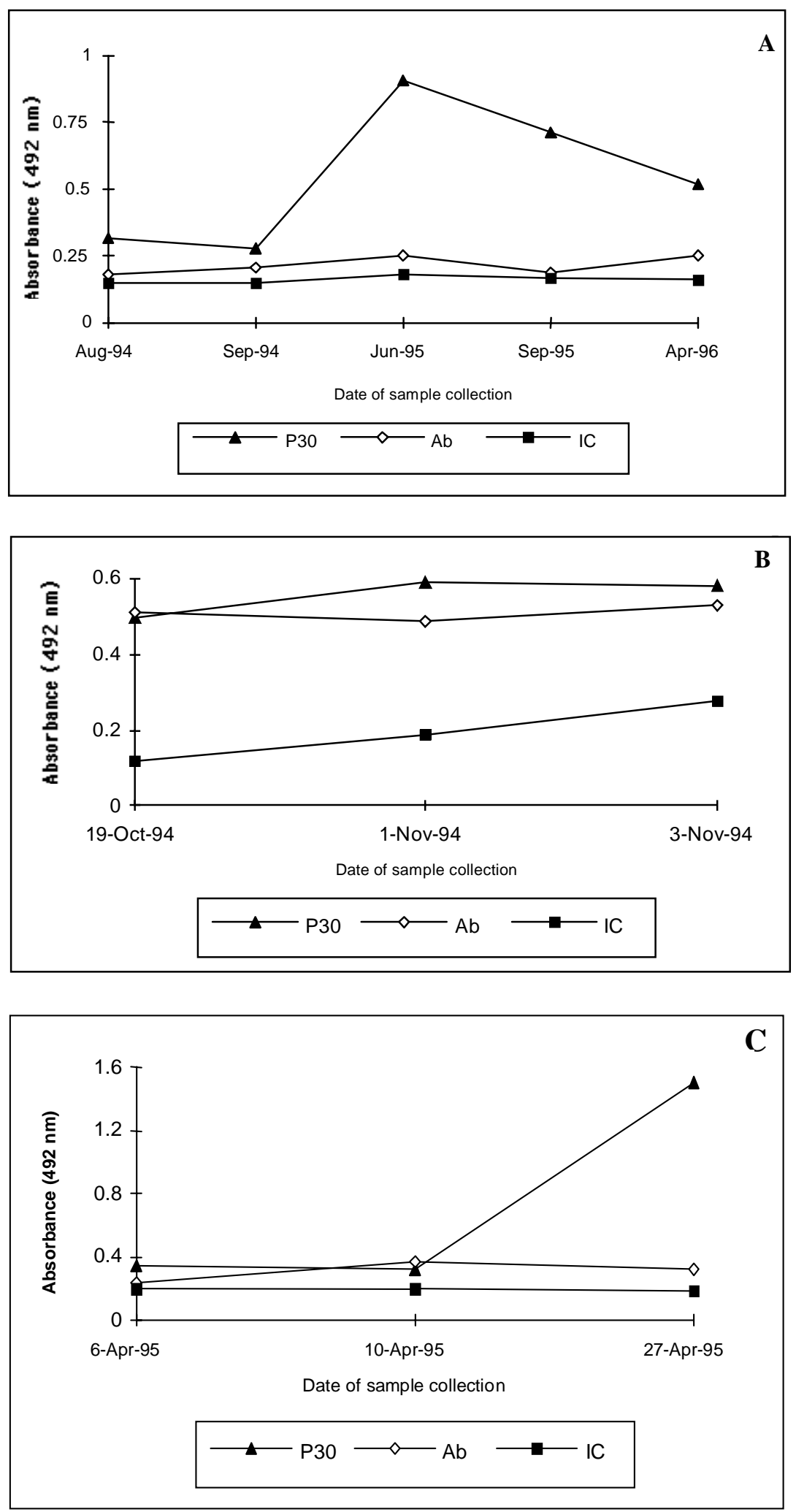

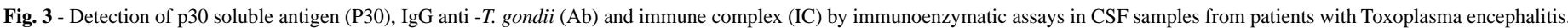
(A) D.M.F., HIV-seropositive, 35 year-old, female; (B) N.P.S., HIV-seropositive, 48 year-old, male; (C) D.F.S., HIV-seropositive, 18 year-old, male. 


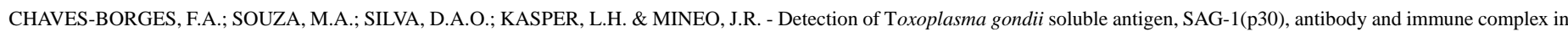
the cerebrospinal fluid of HIV positive or negative individuals. Rev. Inst. Med. trop. S. Paulo, 41(6): 329-338, 1999.

The present study characterizes the profile of the simultaneous detection of $\mathrm{p} 30$ antigen of $T$. gondii, antibody and immune complex in CSF samples of HIV seropositive and seronegative individuals. Among 263 CSF samples randomly collected, approximately one third came from HIV positive patients. These data demonstrate the high index of HIV patients among those searching for medical assistance, probably because they do have developed neurological disorders, indicated by the fulfillment of lumbar puncture to obtain CSF samples.

The high prevalence of anti-T. gondii antibodies (62\%) among the samples tested reflects the high degree of the infection in the region. This prevalence did not differ between positive and negative HIV samples. These results are consistent with studies that suggest toxoplasmic encephalitis in AIDS is due to reactivation of latent infection than acquired acute infection $^{29}$. These results also suggest that the reactivation of the infection may be correlated with p30 levels at CSF. Since p30 is a stage-specific marker for the tachyzoites, it is indicator of active disease. Considering the high prevalence of the $T$. gondii infection among the HIV positive samples, it has to point out the importance of the knowledge of the reactivity profile for toxoplasmosis since that positive results can alert to future complications coming upon from AIDS.

The presence of $\mathrm{p} 30$ antigen among HIV positive (54\%) and negative (40\%) samples was high, indicating that detection of p30 protein has diagnostic value in both groups of patients. Thus, it appears that the rise in p30 levels may be correlated with onset of active infection.

It was shown that p30 antigen was detected in $35 \%$ of the CSF samples which also presented IgG anti-T. gondii antibodies. From the total p30 positive CSF samples, $10 \%$ displayed negative results to antiT. gondii IgG. The absence of anti-T. gondii IgG antibodies in serum and/or CSF samples in patients with toxoplasmosis has been reported in the literature ${ }^{21}$. Circulating antigen of this parasite was detected in serological negative samples in patients with toxoplasmosis ${ }^{16}$ and antigens of molecular weight of $4 \mathrm{kDa}$ were identified ${ }^{33}$. The presence of clinical symptoms suggestive of acquired infection as lymphadenopaty, and negative serology can not exclude the toxoplasmosis diagnosis because the humoral responses in some patients can be delayed creating difficulty in the definitive diagnosis ${ }^{8,20}$.

Although intrathecal antibody production may establish a specific indicator of toxoplasmic encephalitis, approximately $50 \%$ of the patients will not present a detection of antibody in the CSF samples ${ }^{34,40}$. Important differences related to the avidity of the IgG antibody can be detected when it was compared paired samples of the CSF/serum and constitute in a direct indicator of the IgG intrathecal production ${ }^{32}$. The presence of anti-T. gondii $\mathrm{IgG}$ antibodies of low avidity in serum samples of patients presenting recent primary infection was described in the literature ${ }^{18}$. Evidence of compartimentalization of anti- $T$. gondii humoral immune response was observed by the synthesis of $\mathrm{IgG}$ antibodies of low avidity in aqueous humor samples of patients presenting toxoplasmic retinochoroiditis ${ }^{39}$.

The blood-brain barrier may represent an obstacle to immunoglobulin and mononuclear cells passage from the blood to the CSF. This data perhaps can justify the non detection of anti-T. gondii $\mathrm{IgG}$ antibodies in the CSF samples that presented the p30 antigen. However, this antigen can be transported from the blood or from brain extracelullar fluid to the CSF through the cuboid cells of plexus-coroide. Besides molecules that are specifically transported, hydrophobic molecules can exceed the barrier ${ }^{36}$. Perhaps, this fate explains the high incidence of $\mathrm{P} 30$ protein in the CSF samples here examined. It was verified recently, by immunohistochemical studies of the brain, that the incidence of infection of the choroid plexus in AIDS patients with cerebral toxoplasmosis was $53 \%$ in a total of 17 cases $^{11}$.

Presence of immune complex, associated with the absence of detectable levels of antibodies or free P30 can be an indicative of the stage of immune response to the infection. Predominance of immune complex in HIV positive samples may be associated with compromising of the mononuclear phagocytic system responsible for IC clearance from CSF. This could promote a longer persistence of the IC in this and other organic fluids ${ }^{19,22}$.

Combined positive results for $\mathrm{p} 30 / \mathrm{Ab} / \mathrm{IC}$ were more frequent in $\mathrm{HIV}$ positive samples. Among the $62 \%$ of samples with anti- $T$. gondii antibodies, this marker was the only positive reaction in $25 \%$ of the total samples, while p30 or IC were also positive in the remaining $37 \%$. These observations support the hypothesis that the search for the three markers (p30/Ab/IC) might add a new piece of information in the pathogenesis of human toxoplasmic encephalitis. Moreover, detection of p30 in $45 \%$ of the studied CSF samples indicates a high incidence of active infection in the group here included.

Taken into account the results of these three markers, the presence of active infection was detected in CSF samples from patients presenting various clinical data, but it should be pointed out that some of them the first diagnostic hypothesis was not cerebral toxoplasmosis. This emphasizes the clinical application of these assays, with the objective of helping diagnosis and improving prognosis of those patients infected with $T$. gondii.

\section{RESUMO}

\section{Detecção de antígeno solúvel de Toxoplasma gondii SAG-1(p30), anticorpo e imuno complexo em amostras de líquido cefalorraqueano de pacientes HIV positivos ou negativos}

Foi investigada a presença de infecção ativa pelo $T$. gondii em pacientes hospitalizados apresentando acometimentos neurológicos diversos. Amostras de líquido cefalorraquiano (LCR) foram analisadas em imunoensaios padronizados para a detecção de três marcadores moleculares: antígeno solúvel contendo epítopo imunodominante da superfície parasitária SAG-1 (p30), anticorpos específicos e imunocomplexos. Foram coletadas 263 amostras de LCR que foram inicialmente analisadas quanto a presença de anticorpos anti-HIV. Os pacientes foram divididos em dois grupos: HIV positivos $(n=96)$ ou HIV negativos $(\mathrm{n}=167)$. Os resultados dos ensaios demonstraram que $45 \%$ do total de amostras foram positivas para o antígeno SAG-1 (p30). Imunocomplexos foram detectados em $19 \%$ das amostras analisadas e $62 \%$ foram positivas para anticorpos IgG anti-T. gondii. A associação destes resultados com os achados clínicos consistentes com a presença de infecção ativa pelo Toxoplasma pode ser de importância no diagnóstico da encefalite toxoplásmica. 


\section{ACKNOWLEDGMENTS}

The authors thank Dr. Mário E. Camargo and Kenneth Ely for their careful review of this manuscript, Dr. Imtiaz A. Khan for providing us $6 \mathrm{~A} 8 \mathrm{mAb}$ and Dr. Monica Camargo Sopelete for her assistance in the statistical analysis. This project was financially supported by FAPEMIG and CNPq.

\section{REFERENCES}

1. ACEBS, M.V.; DIEZ, B.; GARCIA-RODRIGUES, J.A.; VIENS, P. \& CISTERNA, R. Detection of circulating antigens in the diagnosis of acute toxoplasmosis. Amer. J. trop. Med. Hyg., 51: 506-511, 1994.

2. ARAUJO, F.G. \& REMINGTON, J.S. - Antigenemia in recently acquired acute toxoplasmosis. J. infect. Dis., 141: 144-150, 1980.

3. BESSIÈRES, M.H.; LE BRETON, S. \& SÉGUÉLA, J.P. - Analysis by immunoblotting of Toxoplasma gondii exo-antigens and comparison with somatic antigens. Parasit. Res., 78: 222-228, 1992.

4. BROOKS, R.G.; SHARMA, S.D. \& REMINGTON, J.S. - Detection of Toxoplasma gondii antigens by a dot-immunobinding technique. J. clin. Microbiol., 21: 113$116,1985$.

5. CAMARGO, M.C.V.; ANTUNES, C.M.F. \& CHIARI, C.A. - Epidemiologia da infecção por Toxoplasma gondii no município de Ribeirão das Neves, MG. I. Importância dos animais domésticos como fonte de infecção do T. gondii para o homem. Rev. Soc. bras. Med. trop., 28: 211-214, 1995.

6. CAMARGO, M.E.; FERREIRA, A.W.; MINEO, J.R.; TAKIGUTI, C.K. \& NAKAHARA, O. S. - Immunoglobulin G and Immunoglobulin M enzyme-linked immunosorbent assays and defined toxoplasmosis serological patterns. Infect. Immun., 21: 55-58, 1978 .

7. CESBRON-DELAUW, M.F. \& CAPRON, A. - Excreted/secreted antigens of Toxoplasma gondii: their origin and role in the host-parasite interaction. Res. Immunol., 144: 41-42, 1993.

8. CONTINI, C.; ROMANI, R.; MAGNO, S. \& DELIA, S. - Diagnosis of Toxoplasma gondii infection in AIDS patients by a tissue-culture technique Europ. J. clin. Microbiol. infect. Dis., 14: 434-440, 1995.

9. DUPOUY-CAMET, J.; SOUZA, S.L.; MASLO, C. et al. - Detection of Toxoplasma gondii in venous blood from AIDS patients by polymerase chain reaction. J. clin. Microbiol., 31: 1866-1869, 1993.

10. EGGERS, C.; GROB, U.; KLINKER, H. et al. - Limited value of cerebrospinal fluid for direct detection of Toxoplasma gondii in toxoplasmic encephalitis associated with AIDS. J. Neurol., 242: 644-649, 1995.

11. FAlAngola, M.F. \& PETITO, C.K. - Choroid plexus infection in cerebral toxoplasmosis in AIDS patients. Neurology, 43: 2035-2040, 1993.

12. FLECK, D.G. - Annotation: diagnosis of Toxoplasmosis. J. clin. Path., 42: 191-193, 1989.

13. FRIEDMAN, R.D. - Comparison of four different silver-staining techniques for salivary protein detection in alkaline polyacrilamyde gels. Ann. Biochem., 126: 346-349, 1982.

14. GRINWOOD, J. \& SMITH, J.E. - Toxoplasma gondii: the role of a 30-kDa surface protein in host cell invasion. Exp. Parasit., 74: 106-111, 1992.

15. GROSS, U.; ROGGENKAMP, A.; JANITSCHKE, K. \& HEESEMANN, J. - Improved sensitivity of the polymerase chain reaction for detection of Toxoplasma gondii in biological and human clinical specimens. Europ. J. clin. Microbiol. infect. Dis., 11: 33-39, 1992.
16. HAFID, J.; TRAN-MANH-SUNG, R.; RABERIN, H. et al. - Detection of circulating antigens of Toxoplasma gondii in human infection. Amer. J. trop. Med. Hyg., 52: 336-339, 1995.

17. HARLOW, E. \& LANE, D. - Antibodies. New York, Cold Spring Harbor Laboratory, 1988.

18. HEDMAN, K.; LAPPALAINEN, M.; SEPPÄIÄ, I. \& MÄKELÄ, O. - Recent primary toxoplasma infection indicated by a low avidity of specific IgG. J. infect. Dis., 159: 736-740, 1989

19. HELLERBRAND, C.; GOEBEL, E.D. \& DISKO, R. - High predictive value of Toxoplasma gondii IgG antibody levels in HIV-infected patients for diagnosis of cerebral toxoplasmosis. Europ. J. clin. Microbiol. infect. Dis., 15: 869-872, 1996.

20. HERMENTIN, K.; HASSL, A.; PICHER, O. \& ASPÖCK, H. - Comparison of different serotests for specific Toxoplasma IgM-antibodies (ISAGA, SPIHA, IFAT) and detection of circulating antigen in two cases of laboratory acquired Toxoplasma infection. Zbl. Bakt. Mikrobiol. Hyg., 270: 534-541, 1989.

21. HOLLIMAN, R.E. - Toxoplasmosis and the acquired immune deficiency syndrome. J. Infect., 16: 121-128, 1988.

22. HUNTER, C.A.; SUBAUSTE, C.S.; VAN CLEAVE, V.H. \& REMINGTON, J.S. Production of gamma interferon by natural killer cells from Toxoplasma gondii infected SCID mice: regulation by interleukin-10, interleukin-12, and tumor necrosis factor alpha. Infect. Immun., 62: 2818-2824, 1994.

23. KASPER, L.H.; CRABB, J.H. \& PFEFFERKORN, E.R. - Purification of a major membrane protein of $T$. gondii by immunoabsorption with a monoclonal antibody. J. Immunol., 130: 2407-2412, 1983.

24. KHALIFA, K.E.S.; ROTH, A.; ROTH, B.; ARASTEH, K.N. \& JANITSCHKE, K. Value of PCR for evaluating occurrence of parasitemia in immunocompromised patients with cerebral and extracerebral toxoplasmosis. J. clin. Microbiol., 32: 28132819,1994

25. LAEMLY, U.K. - Cleavage of structural proteins during the assembly of the head of bacteriophage T4. Nature (Lond.), 227: 680-685, 1970.

26. LEBECH, M.; LEBECH, A.M.; NELSING, S.; VUUST, J.; MATHIESEN, L. \& PETERSEN, E. - Detection of Toxoplasma gondii DNA by polymerase chain reaction in cerebrospinal fluid from AIDS patients with cerebral toxoplasmosis. J. infect. Dis., 165: 982-983, 1992.

27. LETILLOIS, M.F.; LAIGLE,V.; SANTORO, S.; MICOUD, M. \& CHUMPOTAZI, B.F - Toxoplasma gondii surface antigen SAG-1 in sera of HIV-infected patients as an indicator of reactivated toxoplasmosis. Europ. J. clin. Microbiol. infect. Dis., 14: 899-903, 1995.

28. LOWRY, O.H.; ROSEBROUGH, N.J.; FARR, A.L. \& RANDALL, R.J. - Protein measurement with the folin phenol reagent. J. biol. Chem., 193: 265-275, 1951

29. LUFT, B.J. \& REMINGTON, J.S. - AIDS commentary: toxoplasmic encephalitis. J. infect. Dis., 157: 1-6, 1988.

30. MINEO, J.R.; CAMARGO, M.E. \& FERREIRA, A.W. - Enzyme-linked immunosorbent assay for antibodies to Toxoplasma gondii polysaccharides in human toxoplasmosis. Infect. Immun., 27: 283-287, 1980.

31. MINEO, J.R.; MCLEOD, R.; MACK, D. et al. - Antibodies to Toxoplasma gondii major surface protein (SAG-1, P30) inhibit infection of host cells and are produced in murine intestine after peroral infection. J. Immunol., 150: 3951-3964, 1993.

32. NARITA, M.; YAMADA, S.; MATSUZONO, Y. et al. - Immunoglobin G avidity testing in serum and cerebrospinal fluid for analysis of measles virus infections. Clin. Diag. Lab. Immunol., 3: 211-215, 1996. 


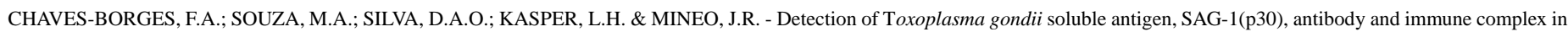
the cerebrospinal fluid of HIV positive or negative individuals. Rev. Inst. Med. trop. S. Paulo, 41(6): 329-338, 1999.

33. POTASMAN, I.; ARAÚJO, F.G.; DESMONTS, G. \& REMINGTON, J.S. - Analysis of Toxoplasma gondii antigens recognized by human sera obtained before and after acute infection. J. infect. Dis., 154: 650-657, 1986.

34. POTASMAN, I.; RESNICK, L.; LUFT, B.J. \& REMINGTON, J.S. - Intrathecal production of antibodies against Toxoplasma gondii in patients with toxoplasmic encephalitis and the acquired immunodeficiency syndrome (AIDS). Ann. intern. Med., 108: 49$51,1988$.

35. RAHMAH, N. \& KHAIRUL, A.A. - Comparison of three forms of antigens in the demonstration of cell-mediated immune response in murine toxoplasmosis. Biochem. biophys. Res. Commun., 189: 640-644, 1992.

36. ROWLAND, L.P.; FINK, M.E. \& RUBIN, L. - Cerebrospinal fluid: blood-brain barrier, brain edema, and hydrocephalus. In: KANDEL, E.R.; SCHWARTZ, J.H. \& JESSELL, T.M., ed. Principles of neural Science. 3. ed. New York, Elsevier Science, 1991. p. 1050-1060.

37. VAN KNAPEN, F. \& PANGGABEAN, S.O. - Detection of circulating antigen during acute infection with Toxoplasma gondii by enzyme-linked immunosorbent assay. J. clin. Microbiol., 6: 545-547, 1977.
38. VELGE-ROUSSEL, F.; CHARDÈS, T.; MÉVÉLEC, P. et al - Epitopic analysis of the Toxoplasma gondii major surface antigen SAG-1. Molec. Biochem. Parasit., 66: 31-38, 1994.

39. VINHAL, F.A.; PENA, J.D.O.; KATINA, J.H. et al. - Analysis of aqueous humor in ocular toxoplasmosis: detection of low avidity IgG specific to Toxoplasma gondii. Appl. Parasit., 35: 1-7, 1994.

40. WAINSTEIN, M.V.; WOLFFENBUTTEL, L.; LOPES, D.K. et al. - Sensibilidade e especificidade do diagnóstico clínico, sorológico e tomográfico da encefalite por Toxoplasma gondii na síndrome da imunodeficiência adquirida (SIDA). Rev. Soc. bras. Med. trop., 26: 571-575, 1988.

41. WEISS, L.M.; UDEM, S.A.; TANOWITZ, H. \& WITTNER, M. - Western blot analysis of the antibody response of patients with AIDS and Toxoplasma encephalitis: antigenic diversity among Toxoplasma strains. J. infect. Dis., 157: 7-13, 1988.

Received: 18 June 1999

Accepted: 05 November 1999 